\title{
Symplectite formation in paragneiss restites from the Gföhl unit, Bohemian Massif
}

\author{
D. SORGER ${ }^{* 1}$, C. A. HAUZENBERGER ${ }^{1}$, F. Finger ${ }^{2}$, M. \\ LINNER $^{3}$
}

${ }^{1}$ University of Graz, Graz 8020, Austria (*correspondence: dominik.sorger@gmail.com)

${ }^{2}$ University of Salzburg, 5020 Salzburg, Austria

${ }^{3}$ Geological Survey of Austria, 1030 Vienna, Austria

An exceptional type of paragneiss restite occurs in the Gföhl unit, southeastern Moldanubian Superunit, Bohemian Massif. The rocks developed a distinct metamorphic layering. Felsic layers are mainly composed of coarse grained (up to 5 $\mathrm{mm}$ ) antiperthitic Pl and Qz, with some interstitial Kfs. Mafic layers consist of $\mathrm{Bt}+\mathrm{Sil}+\mathrm{Grt}+\mathrm{Ilm}+\mathrm{Gr}+\mathrm{Fe}$-sulphides and are riddled with reaction coronas made of $\mathrm{Crd}$ moat and $\mathrm{Crd}$ $+\mathrm{Spl} \pm \mathrm{Cor} \pm \mathrm{An} \pm \mathrm{Bt}$ symplectites particularly at former Grt-Sil interfaces.

Garnet (1-3 mm) commonly shows a grossular-rich $(\sim 6$ mol\%) annulus towards the rim defining a mantle zone, whereas core and rim zones have lower contents ( 3-4 mol\% grs). Inclusions are generally scarce but sometimes Rt can be observed in grossular-rich annuli and Sil in the grs-poor rim zone. In order to constrain the prograde $\mathrm{P}-\mathrm{T}$ evolution the bulk-rock composition was used for thermodynamic modelling. Initial grt growth started approximately at $0.5 \mathrm{GPa}$ and $550{ }^{\circ} \mathrm{C}$. The first metamorphic stage was dominated by pressure increase forming the grs-rich annulus followed by a heating dominated stage towards peak conditions of $\sim 1.0 \mathrm{GPa}$ and $\sim 820{ }^{\circ} \mathrm{C}$. Symplectite formation along the retrograde decompression path occurs only in Bt-Grt-Sil rich zones. The assemblage indicates a local $\mathrm{SiO}_{2}$-understurated and relatively dry composition where following reactions are responsible for symplectite formation:

$$
\begin{gathered}
\text { Grt (alm, prp) }+ \text { Sil } \rightarrow \text { Crd }+ \text { Sp } \\
\& \text { Grt (grs) }+ \text { Sil } \rightarrow \text { An }+ \text { Cor }
\end{gathered}
$$

A representative local symplectite composition was used for thermodynamic modelling to constrain retrograde $\mathrm{P}-\mathrm{T}$ condtions of $\sim 0.5 \mathrm{GPa}$ and $\sim 750-800{ }^{\circ} \mathrm{C}$.

The obtained $\mathrm{P}-\mathrm{T}$ evolution suggests a prograde granulite facies metamorphism in the lower crust ( $\sim 30 \mathrm{~km}$ depth) subsequently followed by nearly isothermal exhumation to upper crustal levels. The extraction of melt near peak conditions most likely is responsible for the dry and restitic composition. This resulted in the preservation of local disequilibria observable through intriguing symplectites. 